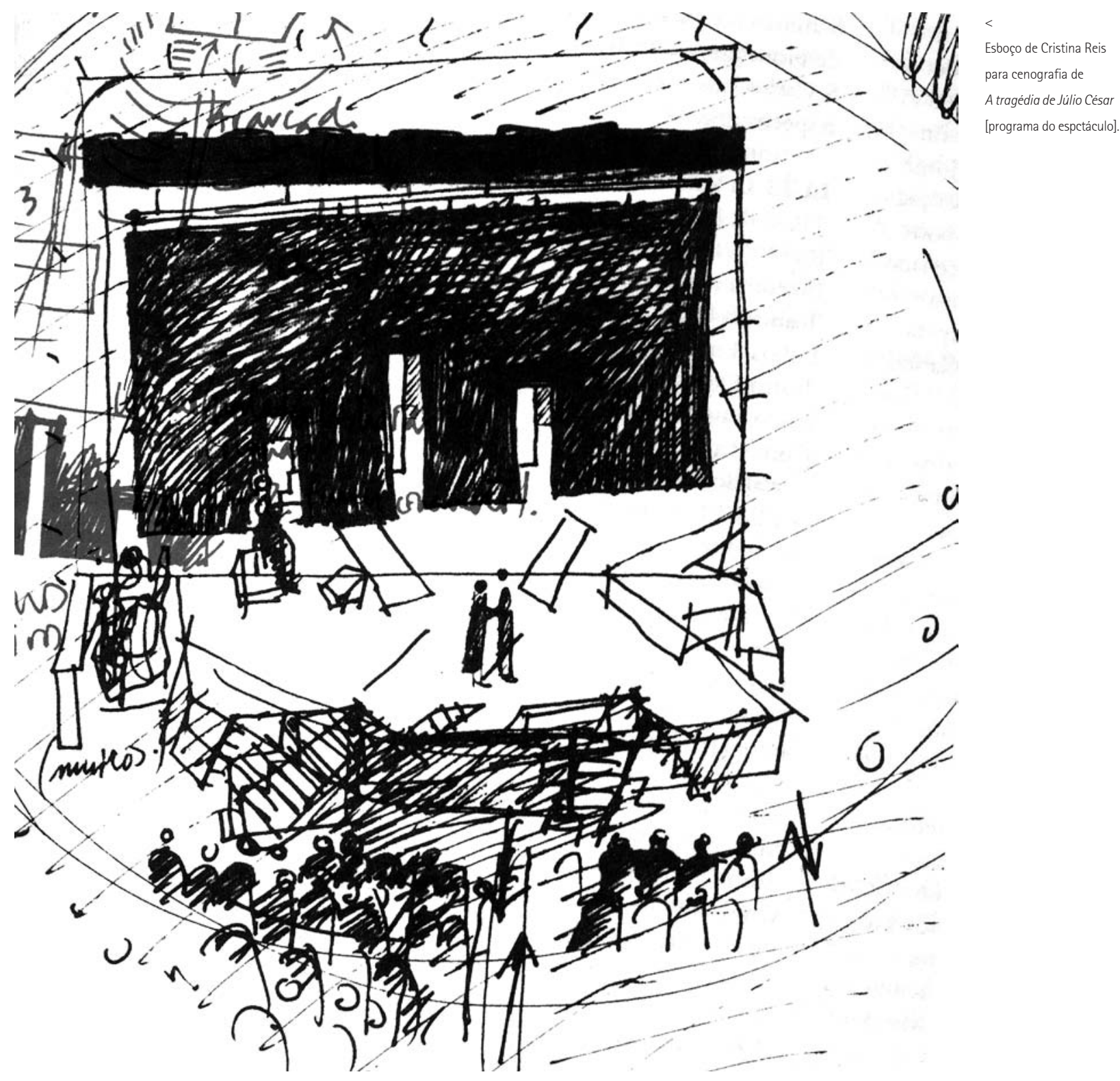

\title{
A inevitável política de um gesto
}

Rui Pina Coelho

Quando a 27 de Março de 2007 assinei a crítica que fiz a este espectáculo para o jornal Público (que titulei "Processo trágico em curso"), terminava com a frase: "é para isto que o teatro serve". E se, por vezes, há frases a que o passar do tempo vem, sinuosamente, retirar alguma da sua original justeza, esta julgo que ainda traduz a enorme alegria e a profunda inquietação que foi assistir a este espectáculo: "é para isto que o teatro serve", escreveria outra vez.

0 espectáculo A tragédia de Júlio César' congregou várias circunstâncias extraordinariamente felizes. Em primeiro lugar, foi a primeira vez que se apresentou este texto em Portugal - não obstante de, em 1964, o Teatro do Ateneu de Coimbra ter solicitado permissão à Comissão de Exame e Classificação de Espectáculos para representar este texto de William Shakespeare - intento toscamente indeferido pelo censor com o argumento de que a peça "só poderá ser aprovada com inúmeros cortes. Considera-se pouco conveniente fazer cortes em textos de autores como este"...

Em segundo lugar, resultou de um esforço de produção entre o Teatro da Cornucópia e o São Luiz Teatro Municipal, uma entidade que, solidamente, se vai constituindo como um dos mais cativantes espaços teatrais da capital, sendo que este espectáculo contribuiu determinantemente para a consolidação deste estatuto.

Em terceiro lugar, a tradução do texto - com a qualidade e rigor a que nos habituou já a "parceria" José Manuel Mendes, Luís Lima Barreto e Luís Miguel Cintra resultou em mais um volume da colecção de teatro dos Livros Cotovia.
Uma análise mais

pormenorizada deste espectáculo encenado por Luis Miguel Cintra foi publicada no número 7 desta revista: Maria Helena Serôdio, "Uma perturbadora encenação da realidade", pp. 84-87. 
Esboço de Cristina Reis para cenografia de A tragédia de Júlio César [programa do espectáculo]. Throgra

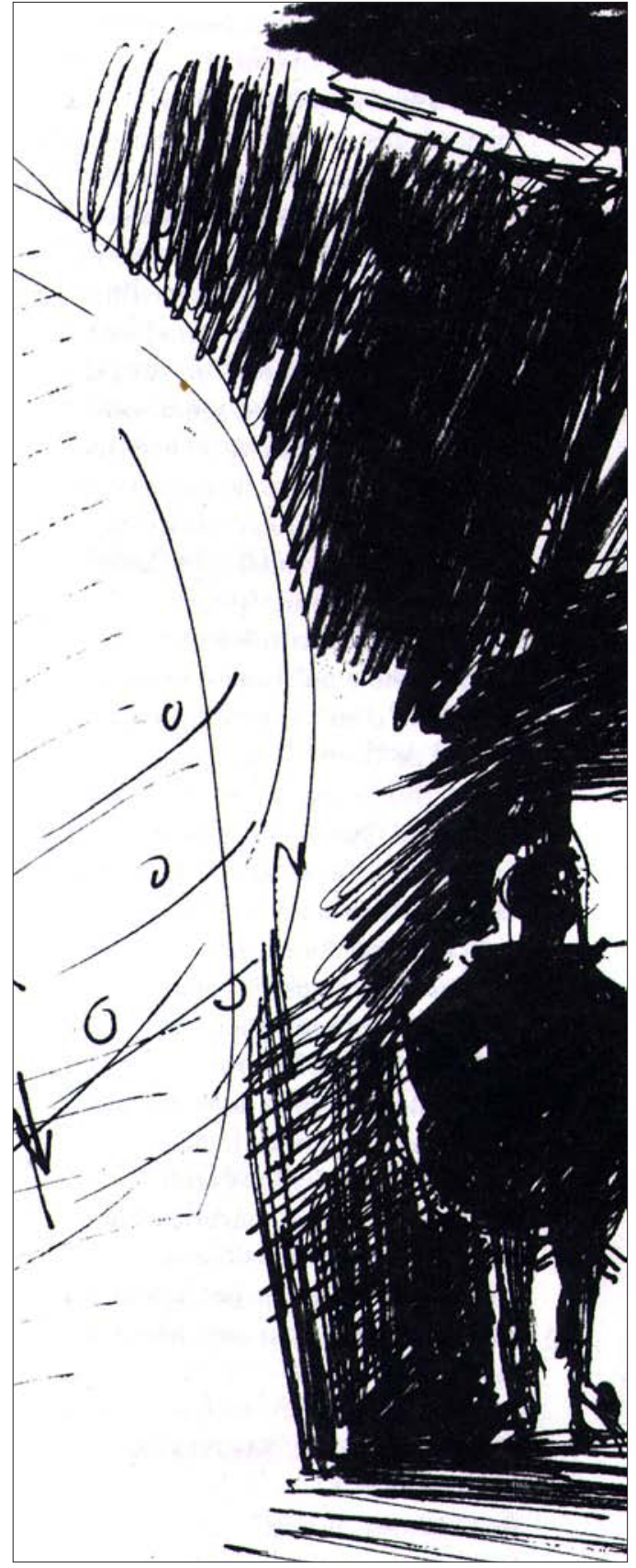

nomeado pela APCT a reconhecer a excelência e a singularidade de A tragédia de Júlio César é o desassombro e a lucidez com que o texto de Shakespeare serviu para tratar temas tão prementes como a guerra e o poder e para fazer uma descomplexada análise da mais recente história nacional e do actual panorama internacional. Ainda que se ancorasse a leitura numa observação atenta da palavra shakespeariana, a encenação de Luís Miguel Cintra convocava, de uma maneira surpreendente e fulgurante, as convulsões do pós-25 de Abril de 1974 e da guerra no Iraque (e, em última instância, de todas as guerras de todos os tempos e em todas as partes).

Este exigente exercício, que obriga a reconhecer a falência da Revolução, abriga também o corajoso gesto de encontrar optimismo na dissecação do fracasso. Tudo isto fez de A tragédia de Júlio César um espectáculo com memória e, simultaneamente, brutalmente eficaz no diálogo com o presente. E sim, é para isto que o teatro serve. 